ISSN 1112-9867

Available online at http://www.jfas.info

\title{
EXPERIMENTAL DETERMINATION OF OCTANOL-WATER PARTITION COEFFICIENTS OF FERROCENE DERIVATIVES USING SQUARE WAVE VOLTAMMETRY TECHNIQUES
}

\author{
R. Ahmedi*, T. Lanez \\ University of El Oued, VTRS laboratory, faculty of Sciences and Technology, PO Box 789, \\ 39000, El Oued, Algeria
}

Received: 15 May 2017 / Accepted: 30 December 2017 / Published online: 01 January 2018

\begin{abstract}
An electrochemical method based on square wave voltammetry was developed for the measurement of octanol-water partition coefficient, LogP, for ten ferrocene derivatives. Measured LogP values ranged over two orders of magnitude, between 2.18 for 1ferrocenylethanol and 4.38 for ferrocenyl-2-nitrophenyl. The measured $\log \mathrm{P}$ values were compared with those obtained by theoretical calculations developed on the basis of the adaptation of the Rekker method. The correlation coefficient of 0.992 for the comparison of experimental $\log \mathrm{P}$ values with those obtained by theoretical calculations indicates an excellent agreement.
\end{abstract}

Keywords: Partition coefficients, $\log P$, ferrocene derivatives, square wave voltammetry.

Author Correspondence, e-mail: ahmedi25@yahoo.fr

doi: http://dx.doi.org/10.4314/jfas.v10i1.23

\section{INTRODUCTION}

The octanol-water partition coefficient, $P$, is an important parameter used in the assessment of environmental fate and transport of organic chemicals; it is defined as the ratio of the molar concentration of a chemical dissolved at equilibrium in octanol phase $C_{\text {oct }}$ to its molar concentration in aqueous phase $\mathrm{C}_{\mathrm{aq}}[1]$, and is given by the following equation (1), 


$$
\mathrm{P}=\left(\frac{\mathrm{C}_{\mathrm{oct}}}{\mathrm{C}_{\mathrm{aq}}}\right)_{\text {equilibrium }}
$$

Different methods were reported for the determination of octanol-water partition coefficient, all of them are based on the measurement of the concentrations at equilibrium in both octanol and aqueous phases [2], these concentrations are usually calculated from the HPLC retention time [3], using a potentiometric titration technique [4], or using electrochemical methods based on electrochemistry at liquid/liquid interfaces $[5,6]$.

Although, there has been a lot of interest in octanol-water partition coefficient measurements over the past 90 years, only there are very few $\log \mathrm{P}$ values reported for ferrocene derivatives $[7,8]$. The rapid advancement of ferrocene chemistry during the last 50 years, notably in areas related to biology and medicine [9-13], led us to turn our attention to the octanol-water partition coefficients of ferrocene derivatives. We herein present the experimental determination of this very important parameter that quantifies the lipophilicity of these derivatives and shows relationship between their structure and biological activity.

In the present study $\operatorname{LogP}$ values of ten ferrocene derivatives, for which a few experimental data are available, is determined using the slow stirring method. The octanol phase concentration is determined using the peak current of square wave voltammograms.

In order to measure octanol-water partition coefficients of ferrocene derivatives, each ferrocene derivative was dissolved in octanol presaturated with water to a known concentration $C_{\text {initial }}$, water presaturated with octanol was then add and allowed to equilibrate. The concentration of each ferrocene derivative in the octanol phase $C_{\text {oct }}$ was determined by using electrochemical techniques based on square wave voltammetry. The concentration in the aqueous phase $C_{a q}$ was then determined based on mass balance and the partition coefficient was calculated as the ratio of the concentration of each ferrocene derivative in the octanol phase to its concentration in the aqueous phase.

Concentration of each ferrocene derivative in the aqueous phase was calculated using the following equation (2),

$$
V_{\text {oct }} C_{\text {initial }}=V_{o c t} C_{o c t}+V_{a q} C_{a q}
$$

Where $V_{o c t}$ and $V_{a q}$ are respectively the volume of the octanol and the aqueous phases, therefore, the aqueous phase concentration can be determined as indicated in equation (3),

$$
C_{a q}=\frac{V_{o c t}\left(C_{\text {initial }}-C_{o c t}\right)}{V_{a q}}
$$




\section{EXPERIMENTAL}

\subsection{Chemical}

HPLC grade 1-octanol was purchased from Aldrich, water used was purified through a MilliQ Gradient A10 from Millipore (Billerica,MA), ferrocene (99\%) was purchased from Alfa Aesar, All other reagents used were of analytical grade. N-ferrocenylmethylaniline [12], ferrocenyl-2-nitrophenyl [13], N-ferrocenymethyl-N-phenylpropionamide [14], N'ferrocenylmethyl-N'-phenylbenzohydrazide [15], ferrocenyl-4-nitrophenyl [16], $\mathrm{N}$ ferrocenymethyl-N-phenylacetamide [17], 1-ferrocenylethanol [18], N-Ferrocénylmethyl(2cyano) aniline [19], 4-(ferrocenylmethylamino)benzonitrile [19] were all obtained according to literature procedures.

\subsection{Instrumentation and software}

Square wave voltammetry measurements were performed using PGZ301 potentiostat (radiometer analytical SAS) and a voltammetric cell with a volumetric capacity of $50 \mathrm{~mL}$ containing a glassy carbon working electrode (radiometer analytical SAS), a Pt wire counter electrode, and an $\mathrm{Hg} / \mathrm{Hg}_{2} \mathrm{Cl}_{2}$ reference electrode (3.0 M KCl). Solutions were deoxygenated with high purity nitrogen for $3 \mathrm{~min}$ prior to each experiment. Data acquisitions were accomplished with a Pentium IV (CPU 3.0 GHz and RAM $1 \mathrm{~Gb}$ ) microcomputer using VoltaMaster4 software version 7.08 (radiometer analytical SAS). Graphs plot were carried out using OriginLab software version 2.0 (Integral Software, France). Square wave voltammetric measurements were run from 150 to $700 \mathrm{mV}$. The parameters for square wave voltammetric measurements were: the potential step was $15 \mathrm{mV}$, the square wave amplitude was $15 \mathrm{mV}$, the pulse $50 \mathrm{mV}$, and the scan rate was $15 \mathrm{mV} / \mathrm{s}$. All measurements were carried out at room temperature $\left(26 \pm 2{ }^{\circ} \mathrm{C}\right)$. The experimental determination of $\operatorname{LogP}$ of ferrocene derivatives was done during a time course of 2 to 4 days. The results are presented as LogP.

\subsection{Voltammetric measurements}

The square wave voltammetric waveform arises from the superimposition of two waveforms, an incremental staircase potential of amplitude $\Delta \mathrm{E}$, which has a square wave amplitude waveform superimposed on it of magnitude E $[20,21]$. The current is sampled at the lower potential of the of magnitude and then at the higher potential, and the difference between these two currents is the peak current which is proportional to the chemical species concentration over a given concentration range, and is given by the equation (4) [22],

$$
d i_{p}=\frac{2 n^{2} F^{2} r D C E}{R T}
$$


where $d i$ is the peak current, $n$ is the charge, $\mathrm{F}$ is the Faraday constant, $r$ is the electrode radius, $\mathrm{D}$ the diffusion coefficient of the electroactive species in solution, $\mathrm{C}$ is the bulk concentration of the electroactive species, E step potential, $\mathrm{R}$ is the gas constant, and $\mathrm{T}$ is the temperature.

\subsection{General procedure for the preparation of calibration curve}

The stock solution of each ferrocene derivative was prepared by dissolving a known masse $\mathrm{m}$ of the corresponding derivative in a volume $V_{\text {oct }}$ of octanol presaturated with water. The standard solutions were then prepared by diluting, with octanol presaturated with water, an accurately volume $\mathrm{V}$ of the stock solution to a volume $\mathrm{V}_{\mathrm{T}}$. To each diluted solution was added $20 \mathrm{ml}$ of ethanol, $6 \mathrm{~mL}$ of acetone and $0.5 \mathrm{~mL}$ of concentrated sulphuric acid as supporting electrolyte. The acetone is replaced by 5 to $6 \mathrm{~mL}$ of dimethylformamide (DMF) and the sulphuric acid is replaced by $0.25 \mathrm{~g}$ of tetrabutylammonium hexafluorophosphate $\left(\mathrm{C}_{16} \mathrm{H}_{36} \mathrm{~F}_{6} \mathrm{NP}\right)$ in the case when ferrocene derivatives carry an amine function, table 1.

Table 1. Data for the preparation of different calibration curve

\begin{tabular}{clccccc}
\hline $\mathrm{N}^{\circ}$ & Compound & $\mathrm{m}(\mathrm{g})$ & $V_{\text {oct }}(\mathrm{mL})$ & $\mathrm{V}(\mathrm{mL})$ & $\mathrm{V}_{\mathrm{T}}(\mathrm{mL})$ & $C(\mathrm{mM})$ \\
\hline 1 & $\mathrm{FcH}$ & 0.004 & 8 & 2 & 28.5 & 0.188603 \\
2 & $\mathrm{FcCH}(\mathrm{OH}) \mathrm{CH}_{3}$ & 0.007 & 16 & 4 & 30.5 & 0.249365 \\
3 & $\mathrm{FcCH}_{2} \mathrm{~N}(\mathrm{Ph}) \mathrm{COCH}_{3}$ & 0.006 & 12 & 2 & 28.5 & 0.105302 \\
4 & $\mathrm{FcCH}_{2} \mathrm{~N}(\mathrm{Ph}) \mathrm{COCH}_{2} \mathrm{CH}_{3}$ & 0.007 & 14 & 2 & 28.5 & 0.101047 \\
5 & $\mathrm{Fc}_{2}-\mathrm{PhNO}_{2}$ & 0.0035 & 10 & 2 & 28.5 & 0.079970 \\
6 & $\mathrm{Fc}_{-3}-\mathrm{PhNO}_{2}$ & 0.007 & 14 & 2 & 28.5 & 0.114243 \\
7 & $\mathrm{FcCH}_{2} \mathrm{NH}_{-4}-\mathrm{PhCN}$ & 0.005 & 10 & 3 & 28 & 0.169430 \\
8 & $\mathrm{FcCH}_{2} \mathrm{NHPh}$ & 0.007 & 14 & 4 & 29 & 0.236856 \\
9 & $\mathrm{FcCH}_{2} \mathrm{~N}(\mathrm{Ph}) \mathrm{NHCOPh}$ & 0.007 & 14 & 4 & 29 & 0.168086 \\
10 & $\mathrm{FcCH}_{2} \mathrm{NH}-2-\mathrm{PhCN}$ & 0.008 & 16 & 4 & 30 & 0.210846 \\
\hline
\end{tabular}

Calibration curves were prepared by plotting different concentrations of ferrocene derivatives in a volume $\mathrm{V}_{\mathrm{T}}$ of the mixture versus the peaks current obtained from square wave voltammograms. The equation obtained from the linear calibration graph in the studied concentration range for each ferrocene derivative standard solutions is, $y=A x+B$ (where y represents the value of the peak current and $\mathrm{x}$, the value of concentration of standard ferrocene derivatives solutions, expressed as mol/L), table 2. 
Table 2. Standard curve equations and $\mathrm{R}^{2}$ values obtained from the linear calibration graphs

\begin{tabular}{clcc}
\hline $\mathrm{N}^{\circ}$ & Compound & Equation & $\mathrm{R}^{2}$ values \\
\hline 1 & $\mathrm{FcH}$ & $y=1.404 x+0.389$ & $R^{2}=0.995$ \\
2 & $\mathrm{FcCH}(\mathrm{OH}) \mathrm{CH}_{3}$ & $y=0.937 x+0.135$ & $R^{2}=0.999$ \\
3 & $\mathrm{FcCH}_{2} \mathrm{~N}(\mathrm{Ph}) \mathrm{COCH}_{3}$ & $y=0.792 x+0.195$ & $R^{2}=0.998$ \\
4 & $\mathrm{FcCH}_{2} \mathrm{~N}(\mathrm{Ph}) \mathrm{COCH}_{2} \mathrm{CH}_{3}$ & $y=0.973 x+0.266$ & $R^{2}=0.995$ \\
5 & $\mathrm{Fc}_{2}-\mathrm{PhNO}_{2}$ & $y=0.123 x+0.107$ & $R^{2}=0.997$ \\
6 & $\mathrm{Fc}_{3}-\mathrm{PhNO}_{2}$ & $y=0.930 x+0.265$ & $R^{2}=0.999$ \\
7 & $\mathrm{FcCH}_{2} \mathrm{NH}-4-\mathrm{PhCN}$ & $y=0.538 x+0.245$ & $R^{2}=0.991$ \\
8 & $\mathrm{FcCH}_{2} \mathrm{NHPh}$ & $y=0.368 x+0.187$ & $R^{2}=0.999$ \\
9 & $\mathrm{FcCH}_{2} \mathrm{~N}(\mathrm{Ph}) \mathrm{NHCOPh}$ & $y=4.568 x+1.916$ & $R^{2}=0.993$ \\
10 & $\mathrm{FcCH}_{2} \mathrm{NH}-2-\mathrm{PhCN}$ & $y=0.426 x+0.113$ & $R^{2}=0.999$
\end{tabular}

\subsection{General procedure for the preparation of real simple voltammogram}

A known mass $(\mathrm{m})$ of ferrocene derivatives was dissolved in a volume $V_{\text {oct }}$ of octanol presaturated with water and a volume $V_{a q}$ of water presaturated with octanol was then added, the obtained two phases were then shaken for 10-15 minutes. They were then left to stand until phase separation, about 2-4 days. After separation of the two layers, a volume $\mathrm{V}$ of the octanol layer was taken, and $6 \mathrm{~mL}$ of acetone, $20 \mathrm{~mL}$ of ethanol and $0.5 \mathrm{~mL}$ of concentrated sulphuric acid was added to it. The solution was then introduced into the electrochemical cell and the oxidation peak current of the voltammogram was recorded. The acetone is replaced by 5 to $6 \mathrm{~mL}$ of DMF and the sulphuric acid is replaced by $0.25 \mathrm{~g}$ of $\mathrm{C}_{16} \mathrm{H}_{36} \mathrm{~F}_{6} \mathrm{NP}$ in the case when the ferrocene derivatives carry an amine function.

\section{6. $\log P$ measurement of ferrocene}

\subsubsection{Preparation of calibration curve}

Starting from $2 \mathrm{~mL}$ of the stock solution prepared as indicated in table 1, a set of five standard solutions were prepared in the concentration range from 0.188603 to $0.028290 \mathrm{mM}$, table 3 . 
Table 3. Peak current obtained from square wave voltammetry of ferrocene standard solution

\begin{tabular}{ccc}
\hline Standard solution & $\mathrm{C}(\mathrm{mM})$ & $\mathrm{di}(\mu \mathrm{A})$ \\
\hline 1 & 0.188603 & 3.09375 \\
2 & 0.141452 & 2.34375 \\
3 & 0.094301 & 1.62500 \\
4 & 0.047150 & 1.09375 \\
5 & 0.028290 & 0.81250
\end{tabular}

Each standard solution is introduced into the electrochemical cell and the voltammogram is recorded, (Fig.1) (A) shows the obtained voltammogram at different ferrocene concentrations. (Fig.1) (B) shows the calibration curve obtained by plotting different concentrations of ferrocene derivatives versus the peaks current. The equation obtained from the linear calibration graph in the studied concentration range for ferrocene standard solutions is, $y=1.404 x+0.389$ with a correlation coefficient of $\mathrm{R}^{2}=0.995$.

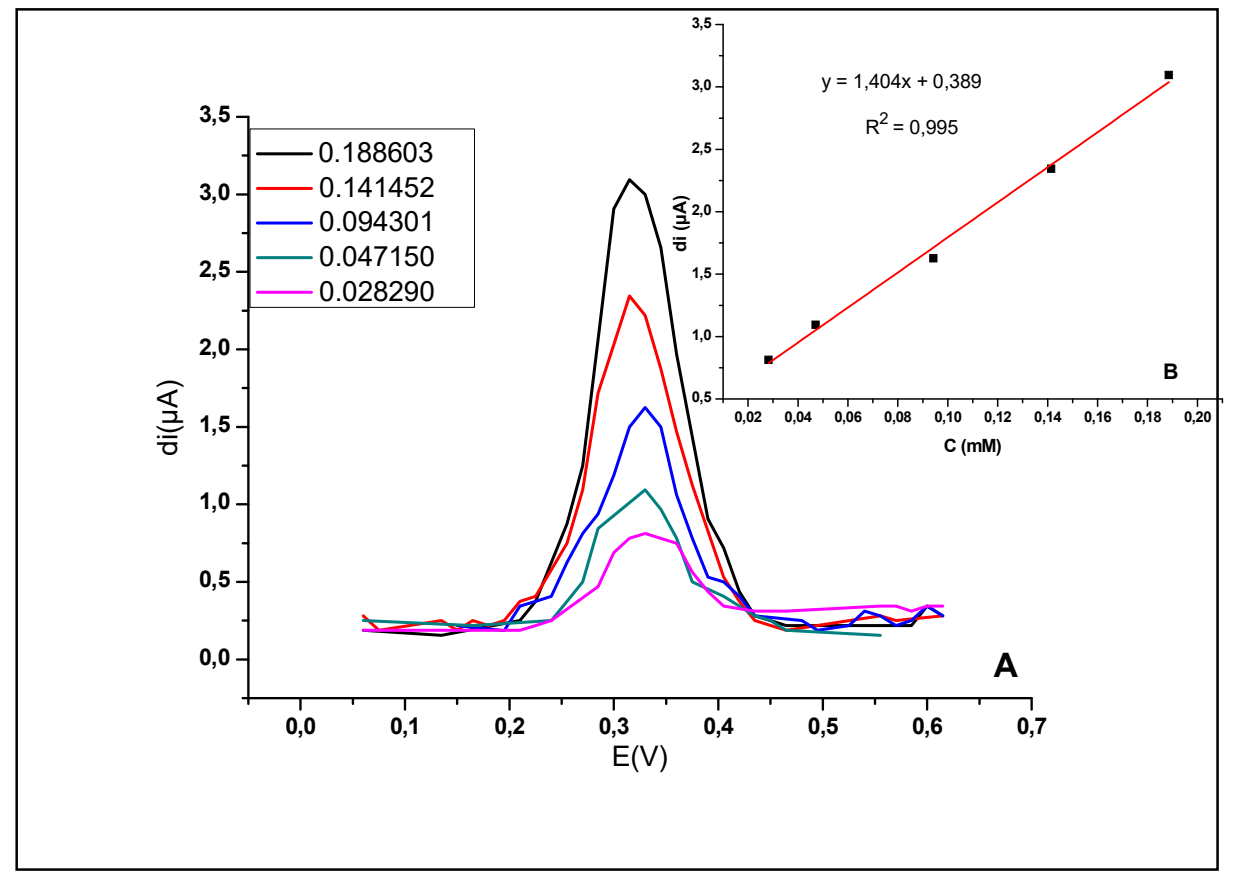

Fig.1. (A) Square wave voltammograms (SWV) referring to different ferrocene concentrations in octanol. (B) Calibration curve obtained from SWV for different ferrocene concentrations in octanol 


\subsubsection{Preparation of voltammogram of the real sample}

Voltammogram of ferrocene was measured by dissolving $0.01 \mathrm{~g}$ of ferrocene in $20 \mathrm{~mL}$ of octanol presaturated with water, thus the initial concentration is equal to $2.687594 \mathrm{mM}, 20$ $\mathrm{mL}$ of water presaturated with octanol was then added and the mixture was then left to stand until phase separation, the two layers were separated and $2 \mathrm{~mL}$ of the octanol layer was then taken and was added to it $6 \mathrm{~mL}$ of acetone, $20 \mathrm{~mL}$ of ethanol, and $0.5 \mathrm{~mL}$ of concentrated sulphuric acid, the resulting solution was then introduced into the electrochemical cell and the voltammogram was recorded, (Fig.2).

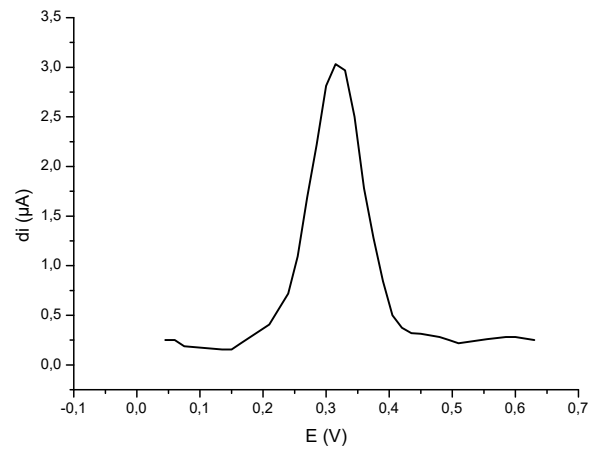

Fig.2. SWV of the real sample of ferrocene in octanol

\subsubsection{LogP determination}

Partition coefficient of ferrocene was measured to validate our method by comparing this value with literature [7].

The concentration of ferrocene in octanol phase $C_{O c t}$ was obtained by replacing the density of the peak current $3.03125 \mu \mathrm{A}$ obtained from the voltammogram of (Fig.2), in the equation $y=1.404 x+0.389$ obtained from the linear calibration graph of (Fig.1(A)), this gives,

$$
x=0.188194 \mathrm{mM}
$$

Thus the number of moles in $28.5 \mathrm{~mL}$ is,

$$
n=0.188194 .10^{-3} \times 28.5 \times 10^{-3}=5.363542 \times 10^{-6} \mathrm{~mol}
$$

$n$, is also equal to the number of moles in $2 \mathrm{~mL}$ taken from the octanol phase, so in $20 \mathrm{~mL}$ of the octanol phase the number of moles is

$$
5.363542 \times 10^{-6} \times 10=5.363542 \times 10^{-5} \mathrm{~mol}
$$

Therefore the concentration of ferrocene in the octanol phase is

$$
C_{\text {oct }}=\frac{5.363542 \times 10^{-5}}{20 \times 10^{-3}}=2.681771 \mathrm{mM}
$$


The concentration of ferrocene in the aqueous phase $C_{a q}^{f r}$ can be calculated based on a mass balance using equation (2)

$$
C_{O c t}=2.687594-2.681771=0.005823 \mathrm{mM}
$$

The partition coefficient is given using equation 1

$$
P=\frac{2.681771}{0.005823}=460.54, \text { and } \log P=2.66
$$

\subsection{LogP measurement of 1-ferrocenylethanol}

\subsubsection{Calibration curve}

Following the same procedure described for ferrocene, a set of four standard solutions were prepared by successive dilution of $4 \mathrm{~mL}$ of the sock solution prepared as describe in table1. The concentration ranges is from 0.249365 to $0.062341 \mathrm{mM}$, table 4 .

Table 4. Peak current obtained from SW voltammetry of 1-ferrocenylethanol

\begin{tabular}{ccc}
\hline Standard solution & $\mathrm{C}(\mathrm{mM})$ & $\operatorname{di}(\mu \mathrm{A})$ \\
\hline 1 & 0.249365 & 2.46875 \\
2 & 0.187024 & 1.88750 \\
3 & 0.124682 & 1.32812 \\
4 & 0.062341 & 0.70625 \\
\hline
\end{tabular}

The obtained square wave voltammogram at different concentrations for each standard solution is shown in (Fig.3 (A)), the calibration curve is shown in (Fig.3 (B)). 


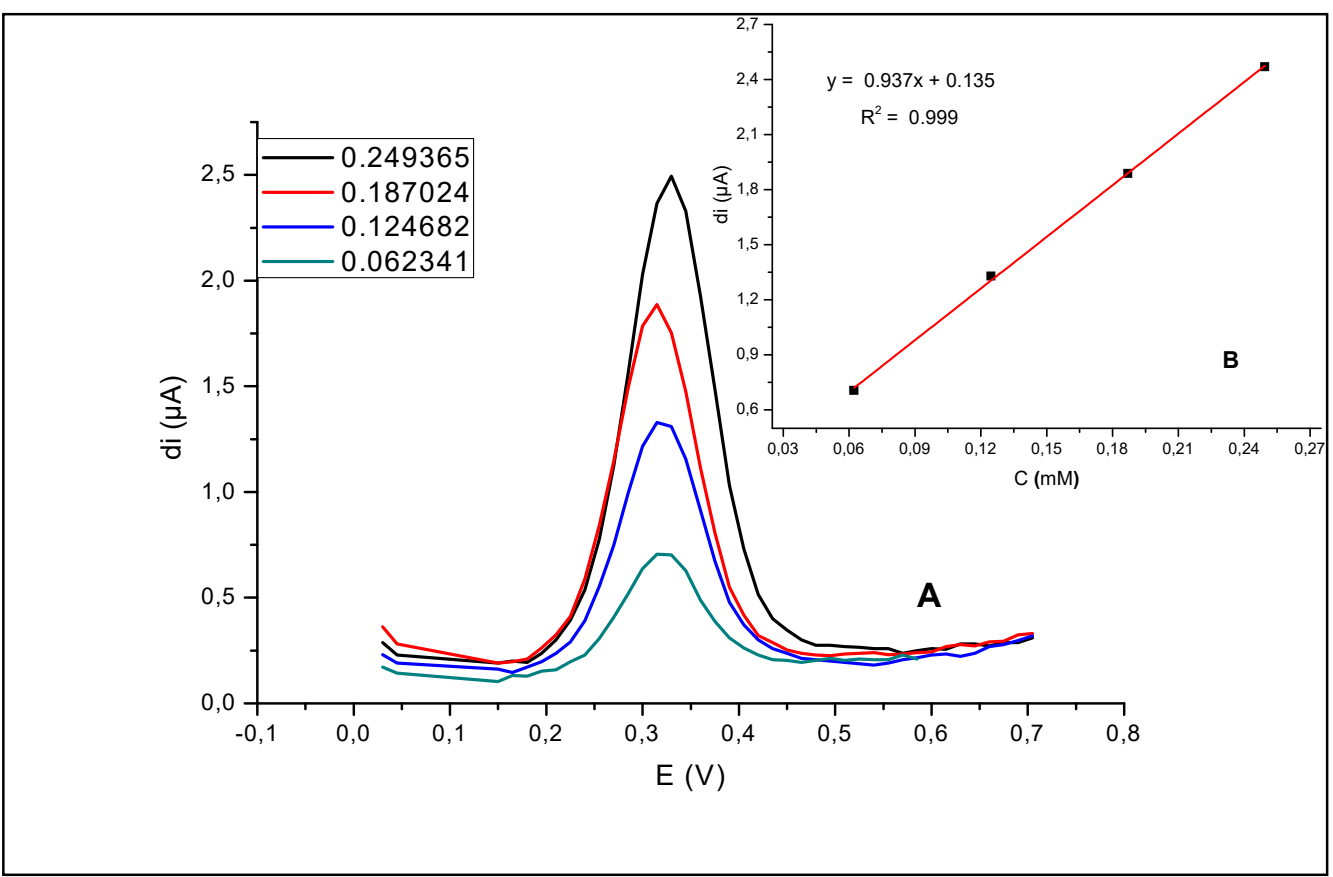

Fig.3. (A) SWV referring to different concentrations of ferrocenylethanol in octanol. (B)

Calibration curve obtained from SWV for different ferrocenylethanol concentrations in octanol

\subsubsection{Preparation of voltammogram of the real sample}

Voltammogram of 1-ferrocenylethanol was measured by dissolving $0.007 \mathrm{~g}$ of this compound in $16 \mathrm{~mL}$ of octanol presaturated with water, $16 \mathrm{~mL}$ of water was then added and the mixture is allowed to equilibrate, the organic layer was separated. To $4 \mathrm{~mL}$ of this layer was added 6 $\mathrm{mL}$ of acetone, $20 \mathrm{~mL}$ of ethanol, and $0.5 \mathrm{~mL}$ of concentrated sulphuric acid. The obtained solution was then introduced into the electrochemical cell and the voltammogram was recorded, (Fig. 4).

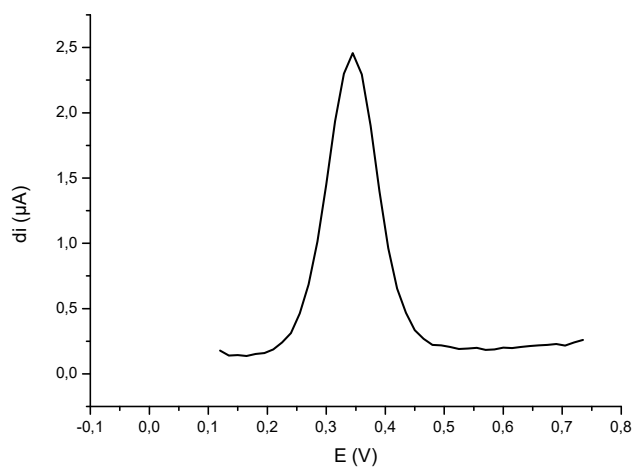

Fig.4. SWV of the real sample of 1-ferrocenylethanol in octanol 


\subsubsection{LogP determination}

The concentration of 1-ferrocenylethanol in octanol phase $C_{O c t}$ is obtained by replacing the density of the peak current $2.45625 \mu \mathrm{A}$ obtained from the voltammogram of (Fig.4) in the equation obtained from the linear calibration graph of (Fig.3 (A)), this gives,

$$
x=0.247732 \mathrm{mM}
$$

Thus the number of moles in $30.5 \mathrm{~mL}$, is

$$
n=0.247732 .10^{-3} \times 30.5 \times 10^{-3}=7.555830 \times 10^{-6} \mathrm{~mol}
$$

$n$, is also equal to the number of moles in $4 \mathrm{~mL}$ taken from the octanol phase, so in $16 \mathrm{~mL}$ of the octanol phase the number of moles is

$$
7.555830 \times 10^{-6} \times 4=30.22332 \times 10^{-6} \mathrm{~mol}
$$

The concentration of 1-ferrocenylethanol in the octanol phase is

$$
C_{O c t}=\frac{30.22332 \times 10^{-6}}{16 \times 10^{-3}}=1.888957 \mathrm{mM}
$$

The concentration of 1 -ferrocenylethanol in the aqueous phase $C_{a q}^{f r}$ is calculated based on a mass balance using equation (2)

$$
C_{a q}=1.901409-1.888957=0.012452 \mathrm{mM}
$$

The partition coefficient is given using equation 1

$$
P=\frac{1.888957}{0.012452}=151.70 \text { and } \log P=2.18
$$

\section{8. $\log P$ measurement of $\mathrm{N}$-ferrocenymethyl- $\mathrm{N}$-phenylacetamide}

\subsubsection{Preparation of voltammogram of the real sample}

The real sample voltammogram of this ferrocene derivatives was measured by dissolving $0.01 \mathrm{~g}$ of $\mathrm{N}$-ferrocenymethyl-N-phenylacetamide in $20 \mathrm{~mL}$ of octanol presaturated with water, thus the initial concentration is equal to $1.500555 \mathrm{mM}$, to this solution was added $20 \mathrm{~mL}$ of water presaturated with octanol, and the mixture was shaken for 10 minutes, and then allowed to stand until the separation of the two layers. $2 \mathrm{~mL}$ of the octanol layer was then taken and 6 $\mathrm{mL}$ of acetone, $20 \mathrm{~mL}$ of ethanol, and $0.5 \mathrm{~mL}$ of concentrated sulphuric acid was added. The resulting solution was then introduced into the electrochemical cell and the square wave voltammogram was recorded, the peak current is $1.0289 \mu \mathrm{A}$, (Fig. 5). 


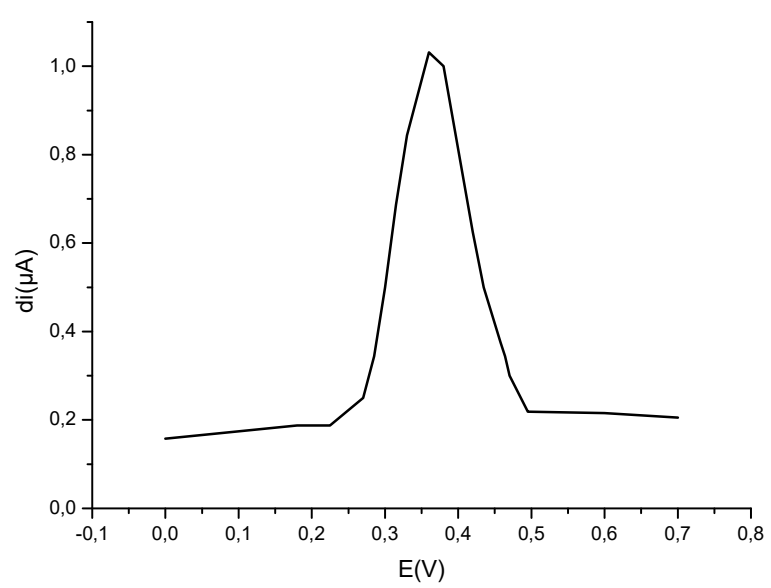

Fig.5. Square wave voltammogram of N-ferrocenymethyl-N-phenylacetamide in octanol after separating the octanol layer

\subsubsection{LogP determination}

Following the same procedure as in ferrocene and 1-ferrocenylethanol we obtain

$$
P=\frac{1.5003882}{1.66943 .10^{-4}}=8987.42, \text { and } \log P=3.95
$$

\subsection{LogP measurement of $\mathrm{N}$-ferrocenymethyl-N-phenylpropionamide}

\subsubsection{Preparation of voltammogram of the real sample}

LogP of $\mathrm{N}$-ferrocenymethyl-N-phenylpropionamide was measured from the square wave voltammogram of (Fig.6) obtained by dissolving $0.01 \mathrm{~g}$ in $20 \mathrm{~mL}$ of octanol presaturated with water, to this solution was added $20 \mathrm{~mL}$ of water presaturated with octanol, and the mixture was shaken for 10 minutes, and then allowed to stand until the separation of the two layers. 2 $\mathrm{mL}$ of the octanol layer was taken and $6 \mathrm{~mL}$ of acetone, $20 \mathrm{~mL}$ of ethanol, $0.5 \mathrm{~mL}$ of concentrated sulphuric acid was added. The solution was then introduced into the electrochemical cell and the voltammogram was recorded, the peak current is $1.24915 \mu \mathrm{A}$, (Fig.6). 


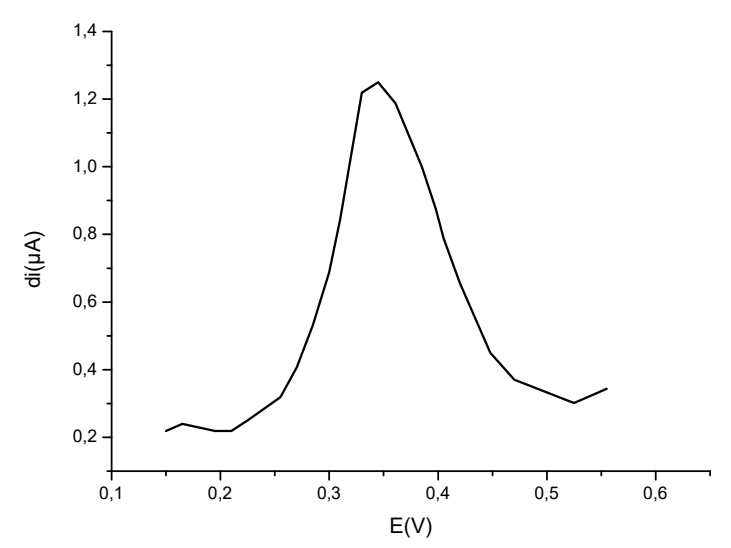

Fig.6. SWV of the real sample of N-ferrocenymethyl-N-phenylpropionamide in octanol

\subsubsection{LogP determination}

Using data in table 6 , we obtain

$$
P=\frac{1.439865}{0.59340 .10^{-4}}=24264.66, \text { and } \log P=4.38
$$

\subsection{LogP measurement of ferrocenyl-2-nitrophenyl}

\subsubsection{Preparation of voltammogram of the real sample}

The voltammogram of the real sample of ferrocenyl-2-nitrophenyl was measured by dissolving $0.007 \mathrm{~g}$ of this derivatives in $20 \mathrm{~mL}$ of octanol presaturated with water, to this solution was added $20 \mathrm{~mL}$ of water presaturated with octanol, and the mixture was shaken for 10 minutes, and then allowed to stand until the separation of the two layers. $2 \mathrm{~mL}$ of the octanol layer was taken and $6 \mathrm{~mL}$ of acetone, $20 \mathrm{~mL}$ of ethanol, $0.5 \mathrm{~mL}$ of concentrated sulphuric acid was added. The solution was then introduced into the electrochemical cell and the voltammogram was recorded, the peak current is $1.0905 \mu \mathrm{A}$, (Fig.7). 


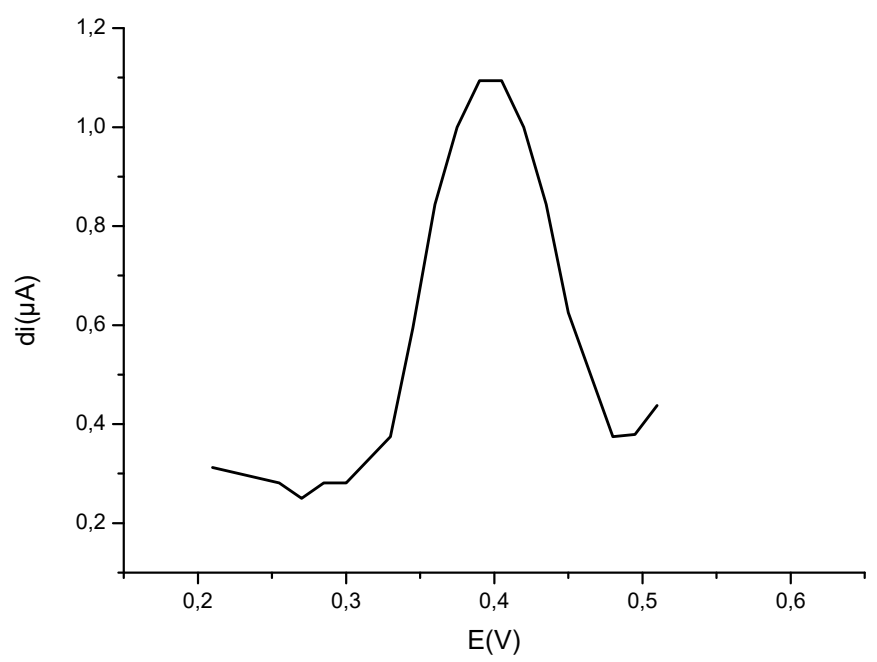

Fig.7. SWV of the real sample of ferrocenyl-2-nitrophenyl in octanol

\subsubsection{LogP determination}

LogP of ferrocenyl-2-nitrophenyl is obtained as follows,

$$
P=\frac{1.139421}{1.50700 .10^{-4}}=7560.85, \text { and } \log P=3.88
$$

\subsection{LogP measurement of ferrocenyl-3-nitrophenyl}

\subsubsection{Preparation of voltammogram of the real sample}

The real sample voltammogram of this ferrocene derivatives was measured by dissolving $0.01 \mathrm{~g}$ of ferrocenyl-3-nitrophenyl in $20 \mathrm{~mL}$ of octanol presaturated with water, this gives an initial concentration of $1.627959 \mathrm{mM}$, to this solution was added $20 \mathrm{~mL}$ of water presaturated with octanol, and the mixture was shaken for 10 minutes, and then allowed to stand until the separation of the two layers. $2 \mathrm{~mL}$ of the octanol layer was taken and $6 \mathrm{~mL}$ of acetone, $20 \mathrm{~mL}$ of ethanol, and $0.5 \mathrm{~mL}$ of concentrated sulphuric acid was added. The solution was then introduced into the electrochemical cell and the voltammogram was recorded, the peak current is $1.32735 \mu \mathrm{A}$, (Fig.8). 


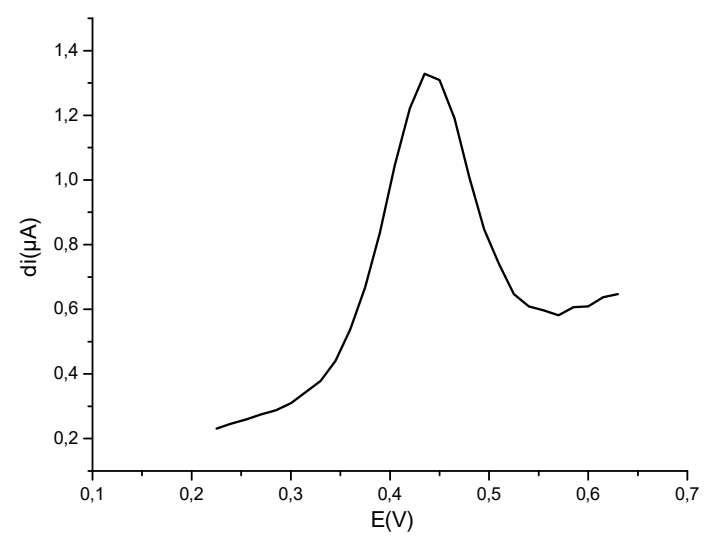

Fig.8. SWV of the real sample of ferrocenyl-3-nitrophenyl in octanol

\subsubsection{LogP determination}

LogP is calculated as follows,

$$
P=\frac{1.627794}{1.64900 .10^{-4}}=9871.40, \text { and } \log P=3.99
$$

\subsection{LogP measurement of 4-(ferrocenylmethylamino)benzonitrile}

\subsubsection{Preparation of voltammogram of the real sample}

This ferrocene derivatives can easily undergoes protonation in acidic medium, in this case sulphuric acid can not be used as supporting electrolyte, and instead $\mathrm{C}_{16} \mathrm{H}_{36} \mathrm{~F}_{6} \mathrm{NP}$ was used in DMF. The voltammogram of compound 4-(ferrocenylmethylamino)benzonitrile was measured by dissolving $0.01 \mathrm{~g}$ of 4-(ferrocenylmethylamino)benzonitrile in $20 \mathrm{~mL}$ of octanol presaturated with water, to this solution was added $20 \mathrm{~mL}$ of water presaturated with octanol, and the mixture was shaken for 10 minutes, and then allowed to stand until the separation of the two layers. $3 \mathrm{~mL}$ of the octanol layer was then taken and $5 \mathrm{~mL}$ of DMF, $20 \mathrm{~mL}$ of ethanol, and $0.25 \mathrm{~g}$ of $\mathrm{C}_{16} \mathrm{H}_{36} \mathrm{~F}_{6} \mathrm{NP}$ were added. The solution was then introduced into the electrochemical cell and the voltammogram was recorded, the peak current is $1.15625 \mu \mathrm{A}$, (Fig.9). 


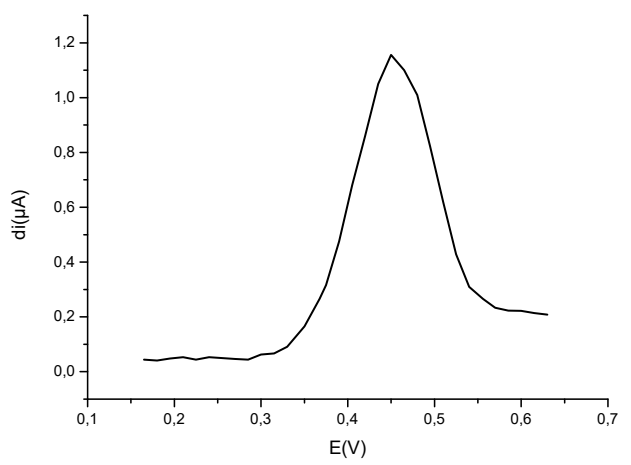

Fig.9. SWV of the real sample of 4-(ferrocenylmethylamino)benzonitrile in octanol

\subsubsection{LogP determination}

LogP is determined as follows,

$$
P=\frac{1.580855}{4.89382 .10^{-4}}=3230.31, \text { and } \log P=3.51
$$

\subsection{LogP measurement of $\mathrm{N}$-ferrocenylmethylaniline}

\subsubsection{Preparation of voltammogram of the real sample}

Acid sulphuric can not be used as supporting electrode because the amine function of $\mathrm{N}$ ferrocenylmethylaniline undergoes protonation in this acid medium, the voltammogram of this ferrocene derivatives was measured by dissolving $0.01 \mathrm{~g}$ of this derivatives in $20 \mathrm{~mL}$ of octanol presaturated with water, to this solution was added $20 \mathrm{~mL}$ of water presaturated with octanol, and the mixture was shaken for 10 minutes, and then allowed to stand until the separation of the two layers. $4 \mathrm{~mL}$ of the octanol layer was taken and $5 \mathrm{~mL}$ of DMF, $20 \mathrm{~mL}$ of ethanol, $0.25 \mathrm{~g}$ of $\mathrm{C}_{16} \mathrm{H}_{36} \mathrm{~F}_{6} \mathrm{NP}$ were added. The solution was then introduced into the electrochemical cell and the voltammogram was recorded, the peak current is $1.0585 \mu \mathrm{A}$, (Fig.10).

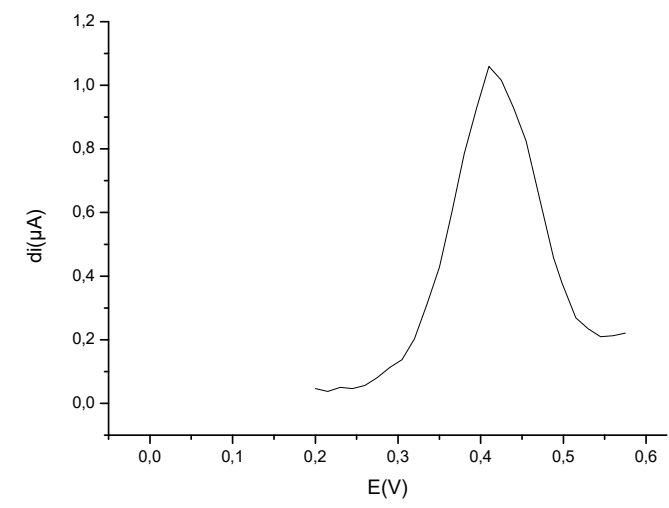

Fig.10. SWV of the real sample of of $\mathrm{N}$-ferrocenylmethylaniline in octanol 


\subsubsection{LogP determination}

$\log \mathrm{P}$ is calculated as follows,

$$
P=\frac{1.716950}{2.60165 .10^{-4}}=6599.46, \text { and } \log P=3.82
$$

\subsection{LogP measurement of $N$ '-ferrocenylmethyl-N'-phenylbenzohydrazide}

\subsubsection{Preparation of voltammogram of the real sample}

The real sample voltammogram of this ferrocene derivatives was measured by dissolving $0.01 \mathrm{~g}$ of N'-ferrocenylmethyl-N'-phenylbenzohydrazide in $20 \mathrm{~mL}$ of octanol presaturated with water, to this solution was added $20 \mathrm{~mL}$ of water presaturated with octanol, and the mixture was shaken for 10 minutes, and then allowed to stand until the separation of the two layers. $4 \mathrm{~mL}$ of the octanol layer was taken and $5 \mathrm{~mL}$ of DMF, $20 \mathrm{~mL}$ of ethanol, $0.25 \mathrm{~g}$ of $\mathrm{C}_{16} \mathrm{H}_{36} \mathrm{~F}_{6} \mathrm{NP}$ were added. The solution was then introduced into the electrochemical cell and the voltammogram was recorded, the peak current is $0.95937 \mu \mathrm{A}$, (Fig.11).

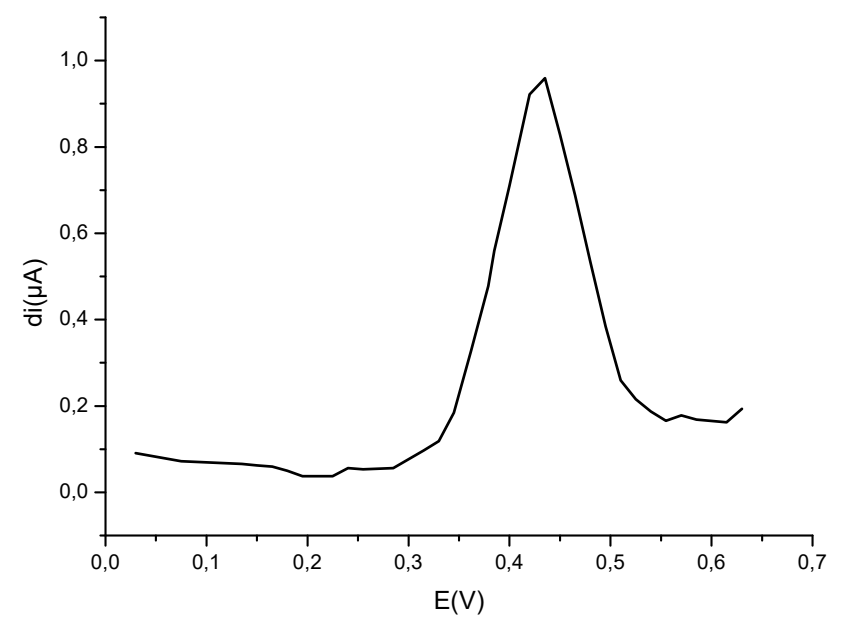

Fig.11. SWV of the real sample of of N'-ferrocenylmethyl-N'-phenylbenzohydrazide in octanol

\subsection{2. $\log P$ determination}

The partition coefficient is given using equation 1 as follows,

$$
P=\frac{1.218549}{0.77656 .10^{-4}}=15691.63, \text { and } \log P=4.19
$$

\subsection{LogP measurement of $\mathrm{N}$-ferrocenylmethyl-2-cyanoaniline}

\subsubsection{Preparation of voltammogram of the real sample}


$\log \mathrm{P}$ of $\mathrm{N}$-ferrocenylmethyl-2-cyanoaniline was measured from the square wave voltammogram of (Fig.12) obtained by dissolving $0.008 \mathrm{~g}$ of $\mathrm{N}$-ferrocenylmethyl-2cyanoaniline in $16 \mathrm{~mL}$ of octanol presaturated with water, to this solution was added $16 \mathrm{~mL}$ of water presaturated with octanol, and the mixture was shaken for 10 minutes, and then allowed to stand until the separation of the two layers. $4 \mathrm{~mL}$ of the octanol layer was taken and $6 \mathrm{~mL}$ of DMF, $20 \mathrm{~mL}$ of ethanol, $0.25 \mathrm{~g}$ of $\mathrm{C}_{16} \mathrm{H}_{36} \mathrm{~F}_{6} \mathrm{NP}$ were then added. The solution was then introduced into the electrochemical cell and the voltammogram was recorded, the peak current is $1.0100 \mu \mathrm{A}$, (Fig.12).

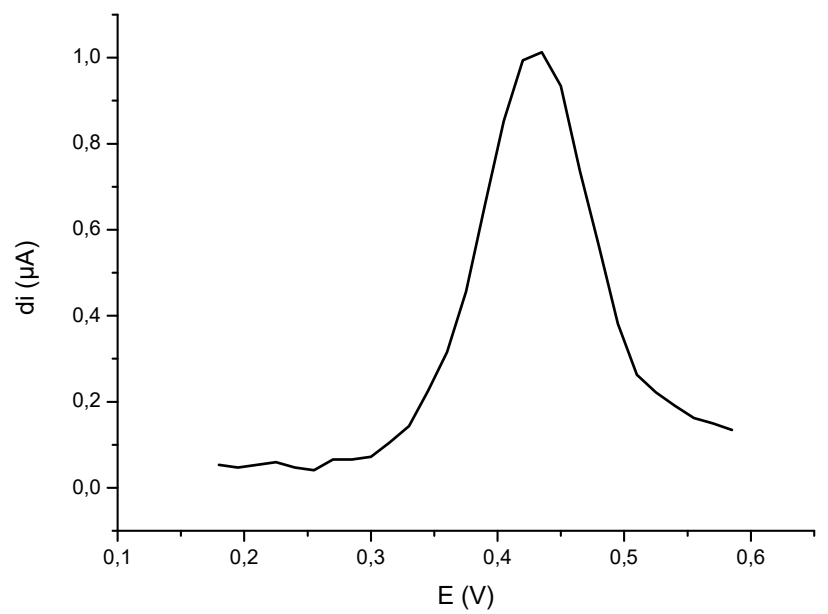

Fig.12. SWV of the real sample of N-ferrocenylmethyl-2-cyanoaniline in octanol

\subsubsection{LogP determination}

The partition coefficient is given using data in table 6 ,

$$
P=\frac{1.580986}{3.58484 .10^{-4}}=4410.20, \text { and } \log P=3.64
$$

$\log \mathrm{P}$ for the ten ferrocene derivatives were summarised in table 5. 
Table 5. Experimental partition coefficients for examined ferrocene derivatives

\begin{tabular}{ccccccc}
\hline $\mathrm{N}^{\circ}$ & Equation & $\mathrm{di}(\mu \mathrm{A})$ & $C_{\text {Oct }}(\mathrm{mM})$ & $C_{a q}(\mathrm{mM})$ & $P_{\text {exp }}$ & $\log P_{\exp }$ \\
\hline 1 & $y=1.404 x+0.389$ & 3.03125 & 2.681771 & 0.005823 & 460.54 & 2.66 \\
2 & $y=0.937 x+0.135$ & 2,45625 & 1.888957 & 0.012451 & 151.70 & 2.18 \\
3 & $y=0.792 x+0.195$ & 1.0289 & 1.500388 & $1.66943 .10^{-4}$ & 8987.42 & 3.95 \\
4 & $y=0.793 x+0.266$ & 1.24915 & 1.439865 & $0.59340 .10^{-4}$ & 24264.66 & 4.38 \\
5 & $y=0.123 x+0.107$ & 1.0905 & 1.139421 & $1.50700 .10^{-4}$ & 7560.85 & 3.88 \\
6 & $y=0.930 x+0.265$ & 1,32735 & 1.627794 & $1.64900 .10^{-4}$ & 9871.40 & 3.99 \\
7 & $y=0.538 x+0.245$ & 1.15625 & 1.580855 & $4.89382 .10^{-4}$ & 3230.31 & 3.51 \\
8 & $y=0.368 x+0.187$ & 1.0585 & 1.716950 & $2.60165 .10^{-4}$ & 6599.46 & 3.82 \\
9 & $y=4.568 x+1.916$ & 0.95937 & 1.218549 & $0.77656 .10^{-4}$ & 15691.63 & 4.19 \\
10 & $y=0.426 x+0.113$ & 1.010 & 1.580986 & $3.58484 .10^{-4}$ & 4410.20 & 3.64 \\
\hline
\end{tabular}

\section{RESULTS AND DISCUSSION}

The experimental values of $n$-octanol-water partition coefficients for the ten studied ferrocene derivatives were compared with the theoretical partition coefficients obtained using the Rekker approach, table 6.

Table 6. Absolute error results between experimental and calculated partition coefficients

\begin{tabular}{|c|c|c|c|c|}
\hline $\mathrm{N}^{\circ}$ & Compound & $\log P_{\text {exp }}$ & $\log P_{\text {theo. }}[23]$ & $\Delta \log P^{*}$ \\
\hline 1 & $\mathrm{FcH}$ & 2.66 & 2.66 & 00 \\
\hline 2 & $\mathrm{FcCH}(\mathrm{OH}) \mathrm{CH}_{3}$ & 2.18 & 2.05 & 0.13 \\
\hline 3 & $\mathrm{FcCH}_{2} \mathrm{~N}(\mathrm{Ph}) \mathrm{COCH}_{3}$ & 3.95 & 4.05 & 0.10 \\
\hline 4 & $\mathrm{FcCH}_{2} \mathrm{~N}(\mathrm{Ph}) \mathrm{COCH}_{2} \mathrm{CH}_{3}$ & 4.38 & 4.57 & 0.19 \\
\hline 5 & Fc-2-PhNO 2 & 3.88 & 4.11 & 0.23 \\
\hline 6 & $\mathrm{Fc}-3-\mathrm{PhNO}_{2}$ & 3.99 & 4.11 & 0.12 \\
\hline 7 & $\mathrm{FcCH}_{2} \mathrm{NH}-4-\mathrm{PhCN}$ & 3.51 & 3.58 & 0.07 \\
\hline 8 & $\mathrm{FcCH}_{2} \mathrm{NHPh}$ & 3.82 & 3.94 & 0.12 \\
\hline 9 & $\mathrm{FcCH}_{2} \mathrm{~N}(\mathrm{Ph}) \mathrm{NHCOPh}$ & 4.19 & 4.32 & 0.13 \\
\hline 10 & $\mathrm{FcCH}_{2} \mathrm{NH}-2-\mathrm{PhCN}$ & 3.64 & 3.58 & 0.06 \\
\hline
\end{tabular}


The linear dependencies were received between experimental n-octanol-water partition coefficients and theoretical partition coefficients (Fig.13). The obtained correlation coefficient value for the linear dependencies between partitions coefficients is 0.992 .

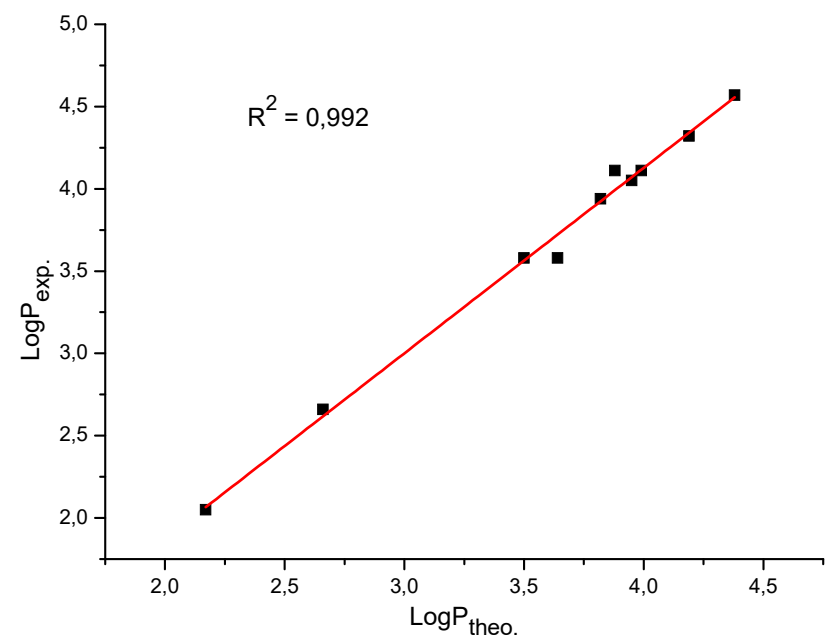

Fig.13. Relationships between the experimental $n$-octanol-water partition coefficients $\log P_{\text {exp. }}$ and theoretical $\log P_{\text {theo. }}$ values

\section{CONCLUSION}

We successfully measured the octanol-water partition coefficients of ten ferrocene derivatives. The measured $\log \mathrm{P}$ values were compared with those obtained by theoretical calculations developed on the basis of the adaptation of the Rekker method. Values of experimental and theoretical $\log \mathrm{P}$ for a series of ten ferrocene derivatives are in good agreement. Our method nicely provides a solution for measuring the partition coefficient of ferrocene derivatives and potentially all analogous organometallic compounds.

The results confirm the utility of use of square wave voltammetry techniques for measuring octanol-water partition coefficients of ferrocene derivatives.

\section{ACKNOWLEDGEMENT}

This research was financed by the laboratory of valorization and technology of Saharan resources, project $\mathrm{N}^{\circ}$. E03220080002. The authors acknowledge the assistance of M. Ali Tliba from laboratory staff.

\section{REFERENCES}

[1] Done R, Mîndril G, Stnculescu I. Anal. Univ. Buc. Chimie, 2007, XVI (1) 83 
[2] Leo A, Hanch C, Elkins D. Chem. Rev., 1971, 71, 526

[3] Boudeville P, Bona M, Burgot J.L. J. Pharm. Sci., 1996, 85, 990

[4] Avdeef A, J. Pharm. Sci., 1993, 82, 183

[5] Kontturi K, Murtomäki L, J. Pharm. Sci., 1992, 81, 970

[6] Ulmeanu SM, Jensen H, Bouchard G, Carrupt PA, Girault HH, Pharm. Res., 2003, 20, 1317

[7] Leo AJ, MedChem, The Medicinal Chemistry Project, Pomona College, Claremont, CA $91711(2000)$

[8] Żabińska A, Różyło JK, Matysiak J, Niewiadomy A, J. Planar Chromatogr., 2000, 13, 420

[9] Halpern J, Pure Appl. Chem., 2001, 209

[10] Fish R. H, Jaouen G. Organometallics, 2003, 22, 2166

[11] Jaouen G. Top S, Vessieres A, Alberto R, J. Organomet. Chem., 2000, 23, 600

[12] Khand I. U, Lanez T, Pauson P. L. J. Chem. Soc., Perkin Trans., 1989, 1, 2075

[13] Lanez T, Pauson P. L. J. Chem. Soc., Perkin Trans., 1990, 1, 2436

[14] Khelef A, Terki B, Mahboub M. S, Lanez T. Acta Cryst., E68, (2012) m647

[15] Terki B, Lanez T, Belaidi S, Gornitzka H, Ourari A. Asian J. Chem., 2006, 18(3), 2074

[16] Roberts D. J, Nolan D, Gearóid M, Máille Ó, Watson G. W, Singh A, Ledoux-Rak I, Draper S. M. Dalton Trans. 2012, 1, 8850

[17] Khelef A, Terki B, Mahboub M. S, and Lanez T., Acta Cryst., 2012. E68, m1318

[18] Watanabe M, Tetrahedron Lett., 1995, 36, 8991

[19] Boubekri C, Khelef A, Terki B. Lanez T. I LCPA, 2015, A27, 49

[20] Osteryoung J, Montenegro M.I. et al. (eds.) Microelectrodes, Theory and Applications, Kluwer, Dordrecht (1991)

[21] Basha C. A, Rajendran L. Int. J. Electrochem. Sci., 2006, 1, 268

[22] Bard A.J, Faulkner L.R, Electrochemical Methods. Fundamentals and Applications, John Wiley \& Sons, Inc., New York (2001)

[23] Ahmedi R, Lanez T, Asian J. Chem., 2010, 22 (1) 299

\section{How to cite this article:}

Ahmedi R, Lanez T. Experimental determination of octanol-water partition coefficients of ferrocene derivatives using square wave voltammetry techniques. J. Fundam. Appl. Sci., 2018, 10(1), 308-327. 